Institute of $\mathbf{F}_{\text {ood and }} \mathbf{A}_{\text {gricultural }} \mathbf{S}_{\text {ciences }}$

\title{
2003 Handbook of Employment Regulations Affecting Florida Farm Employers and Workers: Plant Closing Notification / Layoffs (WARN Act) [Federal] ${ }^{1}$
}

\author{
Leo C. Polopolus, Michael T. Olexa, Fritz Roka, and Carol Fountain ${ }^{2}$
}

\section{Purpose}

To provide employees with notification of intended layoffs or shut-down.

\section{Program / Employer Coverage}

In 1988, Congress passed the Workers Adjustment and Retraining Notification (WARN) Act, also known as the Plant Closing Act. The WARN Act covers employers with (a) 100 or more employees, excluding part-time employees or (b) 100 or more employees who, in the aggregate, work at least 4,000 hours per week.

Covered employers must notify workers of intent to shut down work or discontinue employment for fifty or more workers at a single job site for a period of thirty days or more.

There are no seasonal or agricultural exemptions under the WARN Act.

\section{Notification Process}

- Employers of 100 or more workers must give at least sixty days' advance notice to their employees of a plant closing or mass layoff.

- Seasonal harvests do not exempt employers from the notification requirements of the WARN Act. Note: Seasonal harvests can be exempted if the workers are notified at the time of hiring that the work is temporary.

1. This is EDIS document FE410, a publication of the Department of Food and Resource Economics, Florida Cooperative Extension Service, Institute of Food and Agricultural Sciences, University of Florida, Gainesville, FL. Published July 2003. This information is included in Circular 1200, Handbook of Employment Regulations Affecting Florida Farm Employers and Workers. First published February 1992 as Circular 1043. Revised December 2002 as Circular 1200. Please visit the EDIS website at http://edis.ifas.ufl.edu.

2. Leo C. Polopolus, Professor Emeritus, Department of Food and Resource Economics, University of Florida, Gainesville, FL; Michael T. Olexa, Professor, Department of Food and Resource Economics, University of Florida, Gainesville, FL; Fritz Roka, Associate Professor, Department of Food and Resource Economics, Southwest Florida Research and Education Center, Immokalee, FL; and Carol Fountain, Assistant Editor, Department of Food and Resource Economics, University of Florida, Gainesville, FL; Florida Cooperative Extension Service, Institute of Food and Agricultural Sciences, University of Florida, Gainesville, FL.

This document is designed to provide accurate, current, and authoritative information on the subject. However, since the laws, administrative rulings, and court decisions on which it is based are subject to constant revision, portions of this publication could become outdated at any time. This publication is distributed with the understanding that the authors are not engaged in rendering legal or other professional advice, and the information contained herein should not be regarded as a substitute for professional advice. For these reasons, the utilization of these materials by any person constitutes an agreement to hold harmless the authors, the Institute of Food and Agricultural Sciences, and the University of Florida for any liability claims, damages, or expenses that may be incurred by any person as a result of reference to or reliance on the information contained in this publication.

The Institute of Food and Agricultural Sciences is an equal opportunity/affirmative action employer authorized to provide research, educational information and other services only to individuals and institutions that function without regard to race, color, sex, age, handicap, or national origin. For information on obtaining other extension publications, contact your county Cooperative Extension Service office. Florida Cooperative Extension Service/Institute of Food and Agricultural Sciences/University of Florida/Christine Taylor Waddill, Dean. 
- In addition to notifying employees, employers must notify the workers' collective bargaining agent(s) or representatives (if any) and the state dislocated workers unit, plus the appropriate state and local governmental agencies of closings or layoffs.

\section{Penalties}

If an employer fails to provide the appropriate notification, the employer may be required to pay lost wages and benefits to all laid off employees for a period of up to sixty days.

\section{Definitions}

- Employer. Any business enterprise that employs:

- 100 or more employees, excluding part-time employees.

- 100 or more employees who, in the aggregate, work at least 4,000 hours per week.

- Plant closing. The permanent or temporary shutdown of a single site of employment or one or more facilities or operating units within a single site of employment, if the shutdown results in an employment loss at a single site of employment during any thirty-day period for fifty or more employees.

- Employment loss. This includes:

- An employment termination other than a discharge for cause, voluntary departure, or retirement.

- A layoff exceeding six months.

- A reduction in work hours of more than fifty percent during each month of any six-month period.

- Plant. The term plant is not synonymous with the word building, nor is it necessarily a horticultural term.

\section{Information Required for WARN Notice}

Notice under the WARN Act must contain the following information:

- A statement as to whether the planned action is expected to be permanent or temporary.

- If the entire plant is to be closed, a statement to that effect.

- The expected date when the plant closing or mass layoff will commence and the expected date when the individual employees will be separated.

- An indication of whether or not bumping rights exist.

- The name and telephone number of a company official to contact for further information.

\section{Joint Employment Situations}

Where farm employers also have farm labor contractors (FLC), the 100-worker threshold can be breached in cases of joint employment. In this situation, the number of workers is measured by adding the number of permanent and seasonal workers directly unemployed by the farmer to the number of workers in the FLCs' crews.

\section{Note to Seasonal Agricultural Employers}

For covered agricultural employers, it is suggested that signed releases be obtained at the time of hiring, making it clear to employees that the work is seasonal in nature and that the jobs will end at the conclusion of the task (planting, harvesting, etc.).

\section{Responsible Agency}

U.S. Department of Labor

200 Constitution Avenue, NW

Washington, DC 20210

Dial toll-free 1(800) 487-2365 
http://www.dol.gov 